\title{
PEMBERDAYAAN IBU-IBU PKK KELURAHAN RAWAMANGUN DALAM PELATIHAN PEMANFAATAN LIMBAH KERTAS MENJADI AKSESORIS DENGAN BASIS INDUSTRI KREATIF
}

\author{
E. Lutfia Zahra ${ }^{1)}$, Melly Prabawati $^{2)}$, Vera Utami $\mathbf{G P}^{3)}$ \\ Jurusan IKK Fakultas TeknikUniversitas Negeri Jakarta
}

\begin{abstract}
ABSTRAK
Pengabdian kepada masyarakat merupakan salah satu kegiatan Tri Dharma Perguruan Tinggi yang harus dilaksanakan oleh dosen. Tujuan pengabdian masyarakat adalah meningkatkan pengetahuan dan keterampilan serta mengembangkan kreatifitas ibu-ibu PKK RW 02 dikelurahan Rawamangun.

Jenis kegiatan pengabdian kepada masyarakat adalah pembelajaran tentang keterampilan pembuatan aksesoris dalam limbah kertas berupa kalung, gelang, bros, dan anting anting. Hasil dari kegiatan pengabdian masyarakat ini diharapkan dapat memotivasi masyarakat untuk berwirausaha agar dapat menambah pemasukan ekonomi keluarga.
\end{abstract}

Kata Kunci : Limbah kertas, Aksesoris, Ibu-ibu

\section{PENDAHULUAN}

Kemajuan suatu bangsa tidak dilihat dari seberapa banyak sumber daya alam yang dimiliki oleh negara tersebut, akan tetapi seberapa kreatif sumber daya manusia di negara tersebut dapat memanfaatkan sumberdaya alam yang tersedia. Di Indonesia sudah tidak diragukan lagi tentang pemanfaatan sumber daya alamnya, bahkan negara tetanggapun terkagum-kagum dengan sumber daya alam yang dimiliki negara kita ini. Namun seiring dengan hal tersebut, penggalan kalimat pertama pada latar belakang ini memang sesuai dengan kondisi Indonesia saat ini. Kekayaan alam tidak diimbangi dengan kekayaan intelektual masyarakatnya untuk menciptakan sesuatu yang bermanfaat dan berdayaguna tinggi.

Salah satu contoh di Jakarta. Kota yang menjadi pusat pemerintahan dan pusat perekonomian Indonesia dan juga disebut sebut sebagai miniature Indonesia karena hampir seluruh suku dan ras Indonesia tinggal di Jakarta. Dilihat dari padatnya penduduk di Jakarta, maka masalah berupa kemacetan tak dapat dipungkiri lagi. Kemudian penduduk Jakarta yang setiap harinya memproduksi sampah dan tidak mengolahnya dengan baik berakibat pada sering terjadinya banjir di kota ini. Bukan hanya banjir, ketidak mampuan masyarakat Jakarta untuk mengolah sampah juga berakibat pada banyak nya penyakit yang diderit oleh masyarakat Jakarta yang tinggal dekat dengan tempat pembuangan sampah.

Di sisi lain, kurangnya lapangan pekerjaan juga menjadi masalah yang belum terselesaikan di ibu kota Indonesia ini. Banyak masyarakat Jakarta yang memenuhi lampu merah dan juga pusat keramaian untuk mengamen dan mengemis. Mereka beralasan, sumber daya alam di Jakarta sangat sedikit yang bisa diolah. Namun mereka tetap bertahan di Jakarta dikarenakan sirkulasi uang di sini sngat cepat dan berharap lebih pada warga yang berpenghasilan lebih untuk berkenan memberikan itu ke mereka yang mengemis dan mengamen.

Jika kita lihat lagi dari jumlah kepadatan penduduk dan luas daerah, memang tidak bisa 


\section{P-ISSN : 0216-7484 \\ DOI : doi.org/10.21009/sarwahita.121.03}

dipungkiri bahwa Jakarta tidak memiliki banyak lahan maupun sumber daya alam yang lebih untuk akhirnya bisa dimanfaatkan oleh masyarakatnya. Sementara orang-orang di Jakarta menghasilkan 3 liter sampah setiap harinya (beritabumi.or.id) yang di kalikan dengan jumlah penduduk di kota ini. Bisa terlihat betapa banyaknya sampah yang dihasilkan, namun kurang maksimal dalam penanganannya dan hasilnya pencemaran lingkungan. Dari fenomena tersebutlah semua sampah itu sebagai sebuah peluang sebagai sebuah lapangan pekerjaan yang nantinya juga bisa menambah pendapatan setiap warga.

Salah satu daerah percontohan dalam pengolahan sampah yaitu RW 02 yang terdiri dari beberapa RT dikelurahan rawamangun yang memiliki kepadatan penduduk yang sangat tinggi. Pelatihan pembuatan aksesoris dari limbah kertas akan diadakan di Kelurahan Rawamangun Jakarta Timur. Daerah binaan ini juga pernah dilakukan pelatihan dengan tema yang berbeda yaitu pemanfaatan limbah tekstil hal ini juga sebagai wadah untuk pengaplikasian ilmu yang selama ini telah diterima dan dimiliki oleh mahasiswa. Selain itu, daerah binaan ini bisa menjadi sebuah objek dalam mengaplikasikan Tri Dharma Perguruan Tinggi. Sebagai tenaga pengajar dituntut untuk menciptakan kemandirian di masyarakat agar tujuan negara indonesia memajukan kesejahteraan umum - bisa tercapai. Daerah binaan kegiatan pengabdian masyarakt ini akan dilaksanakan di Kelurahan Rawamangun yang akan melibatkan ibu-ibu PKK warga RW 02. Lingkungan masyarakat disana mempunyai permasalahn kebersihan dan sampah serta kurang adanya kesadaran masyarakat menjadi permasalahan utama.

RW 02 Kelurahan Rawamangun Jl.Pemuda merupakan daerah tepat tinggal padat penduduk yang juga menjadi komplek pasar tradisonal dan banyak usaha foto copy karena dekat dengan lingkungan kampus. Dimana setiap hari terjadi proses perdagangan dan pembuangan kertas sisa yang tidak terpakai di dalamnya. Sehingga tak bisa dipungkiri lagi, sangat banyak sampah yang dihasilkan perharinya dan itu semua hanya dibuang sia sia ke tempat penampungan akhir sampah. Daerah ini juga termasuk dalam tepian sungai. Kemudian kesadaran para warga setempat terkait pendidikan anak anak juga masih kurang.
Sehingga banyak anak anak yang ikut berjualan dengan orang tuanya dan juga ada yang pergi mengamen untuk mencari nafkah. Adapun halnya dengan para ibu-ibu PKKnya, kebanyakan berprofesi sebagai pengangguran dan menghabiskan waktunya untuk hal hal yang kurang bermanfaat, oleh karena itu perlu adanya pelatihan keterampilan membuat aksesoris dari limbah kertas, dengan mengolah sampah agar bisa berkembang menjadi lapangan kerja bagi masyarakat setempat dimana aksesoris juga merupakan salah satu produk busana yang sedang berkembang pesat. Selain bisa menjadi lapangan pekerjaan bagi masyarakat setempat, kegiatan kami ini juga bertujuan untuk menjaga kebersihan lingkungan Jakarta agar terlihat bersih, rapih dan indah agar benar benar pantas menjadi ibu kota Indonesia dan menjadi miniature serta percontohan Indonesia secara keseluruhan.

\section{TINJAUAN PUSTAKA}

\section{A. Aksesoris}

Dalam dunia busana, aksesori (atau aksesoris) adalah benda-benda yang dikenakan seseorang untuk mendukung atau menjadi pengganti pakaian. Bentuk aksesori bermacammacam dan banyak di antaranya terkait dengan peran gender pemakainya. Aksesori dalam bahasa Indonesia hampir selalu berarti fashion accessory dalam penggunaan dalam bahasa Inggris.

Jenis aksesori bermacam - macam, seperti perhiasan (anting-anting atau giwang, kalung, gelang, bros), selendang, sabuk, suspender, dasi,syal, sarung tangan, tas, topi, arloji, kacamata, dan pin. Busana tradisional memiliki aksesori khas yang biasanya dikenakan sebagai perlambang tertentu, seperti destar, sindur, tusuk konde, kembang goyang, dan keris. Adapun contoh aksesoris berikut fungsinya :

1. Cincin (rings)

Cincin merupakan perhiasan yang dipakai pada jari tangan

2. Gelang (bracelets) 
Gelang merupakan perhiasan yang dipakai pada bagian tangan atau kaki

3. Anting (earrings)

Anting merupakan perhiasan yang dipasnag/dipakai pada bagian telinga. Anting dapat dibedakan ats giwang dan anting-anting. Giwang adalah hiasan telinga yang menempel langsung pada telinga, dan bila dipakai tidak bergerak, sedangkan anting-anting adalah hiasan telinga yang apabila dipakai dapat bergerak atau terayun-ayun.

\section{Kalung (necklaces)}

Kalung merupakan perhiasan yang dipakai pada bagian leher. Ukurannya ada yang menempel pada leher (chocker), pendek (beads), sedang (chain), dan panjang (opera lenghth)

5. Jepit rambut/ikat rambut/hiasan kerudung

Sebagai hiasan bagi kaum hawa baik yang memakai kerudung atau yang tidak memakai kerudung. Maka dari itu, aksesoris ini di buat semenarik mungkin dengan karakter dan teknik yang berbeda beda.

6. Jam tangan atau arloji (watch)

Jam tangan merupakan penunjuk waktu yang dipergunakan di pergelangan tangan manusia

7. Kacamata (glasses)

Kacamata merupakan lensa tipis untuk mata guna menormalkan dan mempertajam penglihatan (ada yang berangka dan ada yang tidak). Sekarang selain menjadi alat bantu penglihatan, kacamata juga sudah menjadi pelengkap gaya serta menjadi alat bantu khusus untuk menikmati hiburan seperti kacamata khusus tiga dimensi.

8. Bando

Bentuknya sederhana namun sangat berguna dan fashionist. Fungsi utama dari aksesoris ini sebenarnya adalah penyangga rambut. Namun karena keberagaman bentuk, motif dan warnanya, maka bando pun punya nilai fashion sendiri. Cara pemakaian bando sangat mudah. Kita cukup memposisikan kedua ujung bando masing-masing pada bagian belakang telinga kita dan menggeser bando hingga mengangkat dan menahan rambut kita. Bando memberikan kesan casual dan simple.

\section{B. Limbah Kertas}

Secara umum yang disebut limbah adalah bahan sisa yang dihasilkan dari suatu kegiatan dan proses produksi, baik pada skala rumah tangga, industri, pertambangan, dan sebagainya. Bentuk limbah tersebut dapat berupa gas dan debu,cair atau padat. Berikut identifikasi limbah kertas :

1. Karakter Kertas bekas

Beberapa jenis kertas bekas yang bisa didaur ulang. Namun pendauran ulang kertas hanya bisa dilakukan maksimal 4 6 kali, mengingat serat-serat kertas akan semakin pendek setelah diproses sehingga memengaruhi kekuatan dan ikatan serat dalam kertas. Kertas yang biasdidaur ulang sangat beragam, namun dikelompokkan dalam tiga kategori diantaranya:

a. kertas buangan pabrik kertas,

b. kertas limbah sebelum digunakan konsumen,

c. kertas yang telah digunakan konsumen.

2. Jenis Kertas Bekas

Jenis kertas sangat beragam, mulai dari kertas bergelombang ( dus), kertas bekas koran, kertas bekas majalah, kertas bekas buku telepon, dan kertas bekas kantor/rumah tangga.Pengolahan kertas daur ulang bisa dengan cara sangat sederhana, yaitu kertas hanya diubah bentuknya tanpa perlakuan fisika dan kimia.

Misalnya kertas digunakan untuk dekorasi. Kertas diremas lalu btuk lipatan 
lipatannya dibentuk sesuai selera. Pengolahan kertas secara fisika dan kimia adalah mengolah kertas menjadi bubur kembali, lalu dicetak sesuai dengan keperluannya, baik tipis ataupun tebal. Kertas yang dibuat ubur ini yang hanya bisa didaur ulang hingga 4 - 6 kali, karena serat - serat kertas akan terpotong oleh perlakuan fisika (dihancurkan).

3. Pengolahan Kertas Bekas

Di Indonesia, penggunaan kertas daur ulang untuk bahan baku industri kertas telah banyak dilakukan. bahan baku yang paling banyak di gunakan adalah diperoleh dari kertas bekas kosong, majalah, dan kertas tulis.

Produk kertas daur ulang berupa jenis kertas seperti kertas kemasan atau kertas untuk industri, kertas cetak dan kertas tulis, tissue dan cetakan untuk media massa. Dalam jumlah terbatas, kertas daur ulang dapat juga digunakan untuk media tanaman isolasi, box, produk kertas cetak (wadah telur, karton, baki makanan, dan pot tanaman). Kertas daur ulang ini memiliki beberapa keterbatasan. Produk yang dibuat dari proses ini tidak dapat digunkan untuk kemasan bahan kanan, karena kualitas kertasnya menurun dan dapat mudah terkontaminasi.Khusus untuk daur ulang kertas koran, diperlukan beberapa tambahan proses kimiawi untuk menghilangkan tinta yang ada pada kertas (de-ingking process).

Proses ini menggunakan sabun untuk menghilangkan tinta. Tinta tersebut masih dapat dimanfaatkan untuk kondisi tanah (soil conditioner). kemudian untuk membuat kertas daur ulang yang baik dan dapat digunakan kembali sebagai bahan pembuat koran, dierlukan modifikasi campuran kertas yang terdiri dari atas campuran kertas koran bekas, majalah dan bubur kertas yang asli (virgin pulp) dari bahan baku awal.

\section{Macam-Macam Contoh Aksesoris Dari Limbah Kertas}

1. Kerajinan tangan dengan teknik gintir kertas

Kerajinan tangan dari kertas gintir ini bedasarkan apa yang akan dibuat untuk variasi sesuai keinginan. Hal yang paling populer adalah membuat kupu-kupu, boneka kecil, miniatur orang bahkan ditangan professional kerajinan kertas gintir ini bisa menghasilkan banyak sekali jenis yang dibuat dengan tingkat kerumitan yang sangat tinggi.

2. Kerajinan tangan dari kertas dengan teknik gulung.

Kerajinan tangan dari kertas dengan teknikgulung dapat bervariasi seperti membuat kupu-kupu , kalung kreasi dan sebagainya.

3. Kreasi membuat kalung dari kertas bekas.

Kerajinan tangan dari kertas bekas kali ini membuat sebuah liontin atau kalung.

Adapun Kerajinan dari kertas karton bekas atau kardus bekas. Bahan berjenis karton dan kardus ini akan mensharing tentang Kerajinan dari kertas karton bekas yang sering kita buang. Nah berikut salah contoh gambar kerajinan yang berasal dari bahan karton dan kardus bekas.

\section{Jenis Eksplorasi Kertas Koran Bekas}

1. Pilin

Teknik yang di gunakan adalah dengan memilin kertas koran bekas dan dirangkai menjadi sebuah benda fungsional, kemudian diberi warna yang sesuai.

2. Cetak 
Cetakan dibuat terlebih dahulu, dan bibentuk dengan menggunakan kertas yang sudah dalam bentuk cairan.

3. Tempel

Teknik yang digunakan disini adalah tempel menempel kertas, agar, tanpa adanya teknik khusus.

Mix Material, Material yang digunakan adalah kertas koran bekas dengan menggunakan resin dan pewarnaan hitam.

\section{Produk}

\section{Definisi \& Klasifikasi Produk}

Produk adalah sesuatu yang bisa ditawarkan ke pasar untuk mendapatkan perhatian, pembelian, pemakaian, atau konsumsi yang dapat memenuhi keinginan atau kebutuhan.

Lima Tingkatan Produk Menurut Kotler yaitu : Core benefit, yaitu manfaat dasar dari suatu produk yag ditawarkan kepada konsumen; Basic product, yaitu bentuk dasar dari suatu produk yang dapat dirasakan oleh panca indra; Expected product, yaitu serangkaian atribut-atribut produk dan kondisikondisi yang diharapkan oleh pembeli pada saat membeli suatu produk; Augmented product, yaitu sesuatu yang membedakan antara produk yang ditawarkan oleh badan usaha dengan produk yang ditawarkan oleh pesaing; Potential product, yaitu semua argumentasi dan perubahan bentuk yang dialami oleh suatu produk dimasa datang.

Menurut Kotler (2002,p.451), produk dapat diklasifikasikan menjadi beberapa kelompok, yaitu:

a. Berdasarkan wujudnya, produk dapat diklasifikasikan ke dalam dua kelompok utama. Barang; barang merupakan produk yang berwujud fisik, sehingga bisa dilihat, diraba atau disentuh, dirasa, dipegang, disimpan, dipindahkan, dan perlakuan fisik lainnya; Jasa, merupakan aktivitas, manfaat atau kepuasan yang ditawarkan untuk dijual (dikonsumsi pihak lain). b. Berdasarkan aspek daya tahannya produk dapat dikelompokkan menjadi dua, yaitu: Barang tidak tahan lama, adalah barang berwujud yang biasanya habis dikonsumsi dalam satu atau beberapa kali pemakaian; Barang tahan lama, merupakan barang berwujud yang biasanya bisa bertahan lama dengan banyak pemakaian (umur ekonomisnya untuk pemakaian normal adalah satu tahun lebih).

c. Berdasarkan tujuan konsumsi yaitu didasarkan pada siapa konsumennya dan untuk apa produk itu dikonsumsi, maka produk diklasifikasikan menjadi dua, yaitu: Barang konsumsi, dan barang industri.

Berbicara mengenai produk maka aspek yang perlu diperhatikan adalah kualitas produk. Menurut American Society for Quality Control, kualitas adalah "the totality of features and characteristics of a product or service that bears on its ability to satisfy given needs", artinya keseluruhan ciri dan karakter-karakter dari sebuah produk atau jasa yang menunjukkan kemampuannya untuk memuaskan kebutuhan yang tersirat.

Kualitas produk merupakan pemahaman bahwa produk yang ditawarkan oleh penjual mempunyai nilai jual lebih yang tidak dimiliki oleh produk pesaing. Oleh karena itu perusahaan berusaha memfokuskan pada kualitas produk dan membandingkannya dengan produk yang ditawarkan oleh perusahaan pesaing. Akan tetapi, suatu produk dengan penampilan terbaik atau bahkan dengan tampilan lebih baik bukanlah merupakan produk dengan kualitas tertinggi jika tampilannya bukanlah yang dibutuhkan dan diinginkan oleh pasar.

\section{Karakteristik Produk Menurut WH Mayall}

Dalam bukunya Principle In Design, WH Mayall menerangkan beberapa karak- 
teristik suatu produk. Karakteristik tersebut yaitu :
a. Hasil yang maksimal
b. Biaya yang rendah
c. Harga yang terjangkau oleh pembeli
d. Bentuk yang beragam
e. Penampilan yang menarik
f. Kenyamanan dalam menggunakan
g. Mudah memelihara
h. Aman

\section{MATERI DAN METODE}

\section{A. Bahan dan Alat}

Pada dasarnya pembuatan aksesoris dari limbah kertas alat dan bahan yang di gunakan disesuaikan dengan desain aksesoris yang akan di buat. Adapun alat dan bahan pembuatan aksesoris dari limbah kertas:

1. Limbah kertas/ kardus/ karton/ kertas kado/ kertas daur ulang

2. Gunting

3. Alat tulis untuk membuat desain

4. Rantai kalung

5. Tang khusus aksesoris

6. Lem, Alat Lem Tembak dan Lilin

\section{B. Khalayak Sasaran Yang Strategis}

Khalayak sasaran dalam kegiatan ini adalah sebanyak 20 orang Ibu-Ibu PKK di Kelurahan Rawamangun yang berumur di antara 30-45 tahun, dengan pertimbangan mereka adalah Ibu-Ibu yang masih produktif dan berminat untuk mengembangkan keterampilan.

\section{Metode Kegiatan}

Metode yang akan diterapkan dalam kegiatan ini adalah pre-test dan post-test untuk mengetahui pengetahuan tentang teknik pemanfaatn limbah kertas, ceramah tentang desain produk, teknik pemanfaatan limbah kertas dan wirausaha serta bagaimana penerapan unsur dan prinsip desain pada suatu produk yang memiliki nilai keindahan, kepada khalayak sasaran untuk memperkaya pengetahuan mereka.

Setelah pengetahuan diberi khalayak sasaran mulai dipandu pengenalan alat dan bahan yang akan digunakan untuk teknik pemanfaatan limbah kertas, penerapan desain motif pada produk yang akan dibuat dan proses serta metode teknik pemanfaatan limbah kertas dari berbagai macam pemanfaatan limbah kertas untuk menjadi motif pada aksesoris pelengkap wanita.

Adapun teknik dan langkah kerja yang di gunakan saat proses pembuatan aksesoris :

\section{Langkah Kerja Pembuatan Asesoris dengan Teknik Gulung}

a) Potong kertas bekas dalam bentuk memanjang dengan lebar $2 \mathrm{~cm}$

b) Lipat bagian lebar kertas tersebut sebanyak 2 kali

c) Mulailah menggulung lipatan kertas tersebut dibantu dengan memberi lem pada setiap ujung gulungan serta tarik dan tekan agar gintiran menempel rapi. Buatlah dengan berbagai macam ukuran sesuai dengan desain yang diinginkan.

d) Rekatkan antara satu bagian dengan satu bagian lainnya dengan menggunakan lem uhu atau lem gun, buat sesuai desain yang diinginkan.

e) Setelah semua bagian disatukan, pasang rantai kalung untuk dijadikan kalung atau lem rangkaian gulung dengan peniti bros untuk dijadikan bros maupun satukan dengan kawat anting untuk dijadikan anting.

\section{Langkah Kerja Pembuatan Asesoris dengan Teknik Gintir}

\section{Bahan dan Alat}

1. Kertas bekas

6. Rantai kalung/kawat/pita

2. Lem Uhu

7. Peniti bros

3. Gunting

4. Penggaris

8. Peniti kecil

5. Alat tulis

9. Tang

10. Lem Gun 


\section{Cara Pembuatan :}

1) Potong kertas bekas dalam bentuk segitiga siku dengan lebar $14 \mathrm{~cm}$ dan tinggi $1 \mathrm{~cm}$

2) Gulung perlahan dari bagian yang paling lebar $(1 \mathrm{~cm})$ hingga ke ujung segitiga, lalu beri lem pada ujung segitiga tersebut dan rekatkan.

3) Untuk membuat kalung dan gelang, rangkai tiap gintiran kertas pada tiap-tiap peniti kecil lalu rangkai pada rantai kalung/gelang menggunakan lingkaran kawat. Bentuk sesuai desain yang diinginkan.

4) Untuk membuat bros, sama seperti langkah sebelumnya. Lalu rekatkan beberapa gintiran kertas sebagai penyangga pada peniti bros, kemudian kaitkan beberapa gintiran kertas menggunakan kawat lingkaran buatlah sesuai dengan desain yang diinginkan.

\section{HASIL DAN PEMBAHASAN}

\section{A. Realisasi Kegiatan}

Pemanfaatan limbah kertas sebagai aksesoris yang dimana aksesoris merupakan segala sesuatu yang melekat pada seseorang guna memperindah suatu penampilan seseorang.

Maka dari itu, pemanfaatan limbah kertas dalam bentuk aksesoris untuk meningkatkan kreativitas ibu-ibu PKK di Jl. Pemuda kelurahan Rawamangun. Kegiatan diadakan selama 2 kali pertemuan, yaitu hari jum'at 4 dan sabtu 5 Sepetmber 2015. Peserta yang hadir sebanyak 19 orang. Pada hari pertama, 4 September 2015 peserta diberikan materi tentang macam-macam alat dan bahan yang digunakan untuk mebuat aksesoris, dan teknik yang di gunakan dalam proses pembuatan aksesoris. Pada hari kedua, sabtu 5 september 2015 peserta sudah mempraktekkan dan penyelesaian teknik pembuatan aksesoris yang telah diberikan kepada peserta untuk diterapkan kedalam bentuk aksesoris yakni kalung, gelang, bros dan anting. Kemudian dilakukan penilaian dari hasil karya yang telah dikerjakan. Dalam proses pembuatan aksesoris dari limbah kertas terbagi menjadi empat kelompok dengan dua teknik gintir dan dua teknik gulung.

\section{B. Evaluasi Kegiatan}

Indikator keberhasilan dari kegiatan ini adalah:

1. Ibu-ibu PKK di Kelurahan Rawamangun mempunyai pengetahuan tentang macammacam teknik pemanfaatan limbah kertas.

2. Ibu-ibu PKK di Kelurahan Rawamangun mempunyai pengetahuan tentang alat, bahan dan teknik menghias kain yang diukur berdasarkan hasil pre-test dan posttest.

3. Ibu-ibu PKK di Kelurahan Rawamangun mempunyai kemampuan untuk membuat berbagai produk busana atau pelengkap busana lainnya yang menggunakan teknik pemanfaatan limbah kertas.

4. Ibu-ibu PKK di Kelurahan Rawamangun mempunyai kemampuan untuk produk kerajinan aksesoris dengan teknik pemanfaatan limbah kertas yang memiliki nilai jual dan estetis.

\section{KESIMPULAN}

Pemanfaatan limbah kertas merupakan salah satu keterampilan yang cukup rumit, namun pemanfaatan limbah kertas yang dapat di buat menjadi aksesoris juga memiliki banyak peminat baik peminat untuk sekedar memiliki dan peminat yang juga ingin mempelajari teknik proses pengelolaan limbah kertas menjadi aksesoris tersebut. Maka berkaitan dengan fenomena fashion tersebut perlu adanya pengembangan keterampilan dan desain aksesoris yang sesuai dengan pemanfaatan limbah di sekitar lingkungan masyarakat yang mempunyai nilai fungsional bagi masyarakat khususnya kaum ibu-ibu yang belum memiliki 
kemampuan tersebut tetapi semangat dan ingin mempelajarinya.

Dengan program pelatihan yang berupaya mengembangkan kreativitas para ibuibu yang masih ingin menambah dan mempelajari keterampilan untuk pemanfaatan limbah kertas di sekitar lingkungan Jl. pemuda kelurahan rawamangun.

Program Studi Tata Busana yang didalamnya mempelajari salah satu keterampilan desain akesoris yang akan diterapkan dan berbagi ilmu pada masyarakat khususnya ibu-ibu PKK Jl. Pemuda Kelurahan Rawamangun sehingga dapat meningkatkan pengetahuan, keterampilan dan keahlian kerja ibu-ibu PKK, maka dengan mudah memiliki pekerjaan dan mandiri untuk meningkatkan kreatifitas mereka

\section{DAFTAR PUSTAKA}

Carlotte Kervin, The Classic Techniques, Nederland, 1974

Dewan Kerajinan Nasional, 1981. Sulaman. Jakarta : Museum Tekstil.
Djamadil AA. 1976. Ragam-Ragam Hias, Jilid I. Jakarta : PT. Karya Nusantara.

Harper dan Row. 1987. Voque Sewing for The Home (2nd edition). New York: Publiscrs. Parennial Library

Janice Willams, Lettering in Embroidery, London, 1982

Judi Brittain, Good House Keeping Step - by Step Ency clopa, edia of Nedlecraft, London, 1982

Majalah Gadis. 1985. Tangan Terampil. Jakarta: Redaktur Majalah Gadis.

Magazine, Wall Hanging Quilt, Japan, edisi 2003

Manisha. Creative Neck Designs. Delhi: Indica

Manisha. Tabulous Fashion. Delhi: Indica

Sue Aiken, Applique Quilts, A Craftworid Book, Australia, 1998

Virginia Colton, Complete Guide to Nedlework, USA, 1992 